\title{
OPEN Author Correction: Improving the efficacy of selenium fertilizers for wheat biofortification
}

\section{Chandnee Ramkissoon ${ }^{\infty}$, Fien Degryse, Rodrigo C. da Silva, Roslyn Baird, Scott D. Young, Elizabeth H. Bailey \& Mike J. McLaughlin}

Correction to: Scientific Reports https://doi.org/10.1038/s41598-019-55914-0, published online 20 December 2019

This Article contains a typographical error in the Methods section under subheading 'Selenium fertilizers' where,

'For the treatment with the soil-applied selenate only, a Na2SeO4 solution containing $0.042 \mathrm{mg} \mathrm{Se} \mathrm{L-1} \mathrm{was}$ applied to the soil as $3 \times 26 \mu \mathrm{L}$ droplets, in the same position as the granular fertilizers.'

should read:

'For the treatment with the soil-applied selenate only, a Na2SeO4 solution containing $0.042 \mathrm{~g}$ Se L -1 was applied to the soil as $3 \times 26 \mu \mathrm{L}$ droplets, in the same position as the granular fertilizers.'

\begin{abstract}
(c) (i) Open Access This article is licensed under a Creative Commons Attribution 4.0 International License, which permits use, sharing, adaptation, distribution and reproduction in any medium or format, as long as you give appropriate credit to the original author(s) and the source, provide a link to the Creative Commons licence, and indicate if changes were made. The images or other third party material in this article are included in the article's Creative Commons licence, unless indicated otherwise in a credit line to the material. If material is not included in the article's Creative Commons licence and your intended use is not permitted by statutory regulation or exceeds the permitted use, you will need to obtain permission directly from the copyright holder. To view a copy of this licence, visit http://creativecommons.org/licenses/by/4.0/.
\end{abstract}

(c) The Author(s) 2020 